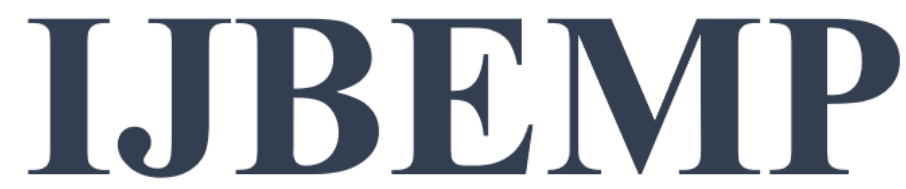

International Journal of Business, Economics and Management Perspectives Uluslararası İșletme, Ekonomi ve Yönetim Perspektifleri Dergisi
ISSN: $2458-8978$

E-ISSN : 2458-8978

YIl Year: 6

Cilt Volume: 5

Sayı Issue : Prof. Dr. Fikret OTLU

Özel Sayısı / Special Issue Eylül September 2021

\title{
SAĞLIK SEKTÖRÜNDE ÖZEL BİR HASTANENIN COSO İÇ KONTROL MODELİ BİLEŞENLERİ ÇERÇEVESINDE İNCELENMESİ
}

\section{Seyhan ÇiL KOÇYİĞíT}

Prof. Dr. Ankara Hacı Bayram Veli Üniversitesi İ̈BF Sağl1k Yönetimi Bölümü, Öğretim Üyesi seyhan.cil@hbv.ed.tr, ORCID: 0000-0003-1012-3605.

\section{Gülay KARACAN}

Ankara Hacı Bayram Veli Üniversitesi Lisansüstü Eğitim Enstitüsü Sağlık Kurumları Yönetimi Bölümü Yüksek Lisans Öğrencisi gulay.karacan@hbv.edu.tr, ORCID: 0000-0002-3894-0140

\section{Betül ATALAY}

Ankara Hacı Bayram Veli Üniversitesi Lisansüstü Eğitim Enstitüsü Sağlık Kurumları Yönetimi Bölümü Yüksek Lisans Öğrencisi betul.atalay@hbv.edu.tr, ORCID: 0000-0001-5370-5176 


\title{
SAĞLIK SEKTÖRÜNDE ÖZEL BİR HASTANENIN COSO İÇ KONTROL MODELİ BÍLEŞENLERI ÇERÇEVESINDE İNCELENMESI
}

\section{ÖZ}

Bütün işletmelerde olduğu gibi hastane işletmelerinde de üst yöneticiler tarafindan belirlenen hedeflere ulaşabilmek için etkili bir iç kontrol sisteminin tasarlanması ve uygulanması son derece önemlidir. Etkili bir iç kontrol sistemi verimliliğin artırılmasında, risklerin önlenmesinde ve işletme amaçlarına ulaşmada katkıda bulunmaktadır. Bu bağlamda bu çalışmada; birden fazla şubesi bulunan özel bir hastanede iç kontrol sisteminin COSO iç kontrol modeli bileşenleri çerçevesinde bu bileşenlere uyum derecesinin çalışanlarca değerlendirilerek, bu değerlendirmelerin farklı direktörlüklerde çalışanlar açısından farklılaşıp farklılaşmadığının ortaya konulması amaçlanmıştır. Araştırmaya katılanların iç kontrol modeline ilişkin ankette yer alan ifadelere yüksek bir oranda $(X=3,81)$ katıldıkları görülmüştür. Alt boyutlar açısından da; en yüksek düzeyli katılımın "izleme" boyutu içerisinde yer alan ifadelere, en düşük düzeyli katılımın ise risk değerlendirme boyutunda yer alan ifadelere ilişsin olduğu görülmüştür. Ayrıca katılımcıların COSO bileşenlerine yönelik değerlendirmeler açısından, çalıştıkları direktörlükler açısından anlamlı bir farklılık olmadığı tespit edilmiştir.

Anahtar Kelimeler: Hastane, İç Kontrol Sistemi, COSO İç Kontrol Modeli

JEL Sınıflandırma Kodları: M42

\section{INVESTIGATION OF A PRIVATE HOSPITAL IN THE HEALTH SECTOR WITHIN THE FRAMEWORK OF COSO INTERNAL CONTROL MODEL COMPONENTS}

\begin{abstract}
As in other businesses, it is extremely important to design and implement an effective internal control system in hospital businesses to achieve the goals set by senior managers. An effective internal control system contributes to increasing efficiency, preventing risks and achieving business goals. In this context, in this study; in a private hospital with more than one branch, it is aimed to evaluate the degree of compliance of the internal control system with these components within the framework of the COSO internal control model components by the employees and to reveal whether these evaluations differ in terms of employess in different directorates. It was observed that the participants of the research highly agreed $(X=3,81)$ with the expressions in the questionnaire regarding the internal control model. In terms of sub-dimensions; it was observed that the highest level of participation was related to the statements in the 'monitoring' dimension, while the lowest level of participation was related to the statements in the risk assessment dimension. Moreover, it was determined that there was no significant difference in terms of the evaluations of the participants' COSO components, in terms of the directorates they worked with.
\end{abstract}

Keywords: Hospital, Internal Control System, COSO Internal Control Model

JEL Classification Codes: M42 


\section{GíRiş}

Ekonomik şartların her geçen gün değişiklik göstermesi, hızla büyüyen işletmelerde her geçen gün rekabet baskısının artması, işletmelerin kurumsal yönetim ilkelerine uygun bir şekilde varlığını devam ettirebilmesi gibi sebeplerle iç kontrol sistemi önem kazanmıştır. Öncelikle kamu sektöründe görülmeye başlanan iç kontrol; işletmelerin faaliyetleri ve işlemlerine yönelik her türlü politika ve prosedürlerden oluşmaktadır. İç kontrol sisteminin amacı; sürece odaklanılması nedeniyle risklerin önceden görülerek değerlendirilmesi ve değişen şartlarla birlikte işletmelerin karşı karşıya kaldıkları bir takım risklere karşı önlemler almasıdır.

Etkin bir iç kontrolün sağlanabilmesi için hem muhasebe kontrolü hem de yönetsel kontrol sağlanabilmeli ve işletmelerin amaçlarına ulaşabilmesi için iç kontrol sistemine alt çalışandan en üst yönetime kadar tüm çalışanlar katılmalıdır. İç kontrol sistemini etkin bir şekilde uygulayan işletmeler; süreci gözden geçirmekte, mevcut ve olabilecek riskleri ortaya koymakta, personellerinin görev, yetki ve sorumluluklarını net olarak belirlemekte, finansal tabloların hatalı ve düzensiz olma olasılığını azaltmaktadır. Bu nedenle de işletmelerde etkin bir iç kontrol sistemi oluşturulmalı ve bu iç kontrol sistemi oluşturulurken iyi hazırlanmış muhasebe sistemine, bir organizasyon planına ihtiyaç olduğu göz önünde bulundurulmalıdır.

Toplum içerisinde oldukça önemli bir konuma sahip olan hastanelerde de diğer işletmelerde olduğu gibi kaynakların etkin bir şekilde kullanılması ve süreçlerindeki risklere odaklanarak önlemler alınması istenmektedir. Hastane işletmelerinde oluşabilecek riskler kurumla birlikte hem çalışanları hem de hastaları etkileyebilecek olduğundan hastanelerde de risklerin iyi yönetilmesi gerekmektedir. Bunların yanı sıra; hastane işletmelerinin oldukça karmaşı bir yapıya sahip olması bu işletmelerde etkin bir şekilde işleyen iç kontrol sisteminin varlığına ihtiyacı artırmaktadır.

Ülkemizde sağlık hizmeti sunan işletmeler arasında özel hastaneler önemli bir paya sahiptir. Bu nedenle vermiş oldukları hizmetin kaliteli olması toplum için oldukça önemlidir. Özel hastanelerin de; kaliteli hizmet vermek için etkin bir iç kontrol sistemine sahip olmaları beklenmektedir. Özel hastane işletmelerindeki iç kontrol sistemi; hastanenin varlıklarının etkin bir şekilde kullanımını sağlarken israfları ortadan kaldırmaya, personellerin hastane işletmesinin amaç, hedef ve politikalarına bağlı kalmasını sağlayarak personel devir hızının düşmesine, verimliliğin, etkililiğin sağlanarak karın da arttırılmasına katkı sağlayacaktır. Böylece kurulacak olan bir iç kontrol sistemi, hastane işletmelerinin daha kaliteli hizmet vermesini sağlayacak ve toplumun da daha kaliteli hizmet almasını sağlamış olacaktır.

İç kontrol sistemiyle ilgili literatürde hem ulusal hem de uluslararası düzeyle birçok çalışma yapılmış olmasına rağmen hastane işletmelerini içeren bu çalışmaların yetersiz olduğu dikkati çekmektedir. $\mathrm{Bu}$ nedenle de bu çalışmada, özel bir hastanede iç kontrol sistemi bileşenleri çerçevesinde etkin bir iç kontrol sisteminin olup olmadığının hastane idari personeli tarafından değerlendirilmesine yer verilmiş̧ir.

Çalışmada öncelikle, iç kontrol sistemine ve sağlık işletmelerinin yapısına genel bir çerçeveden bakılmış; sonra da iç kontrol sistemi ve COSO iç kontrol modeli ve özel hastanelerde iç kontrol sisteminden bahsedilmiştir. Çalışmanın uygulama bölümünde ise; özel bir sağlık grubunun idari personeline yapılan anket uygulamasıyla ilgili hastanede COSO iç kontrol modeline uyum derecesinin çalışanlarca değerlendirilmesine yer verilmiştir. Çalışma sonuç ve öneriler bölümüyle tamamlanmıştır.

\section{2. İÇ KONTROL SISTEMI VE COSO İÇ KONTROL MODELİ}

Bu kısımda iç kontrol sistemi ve COSO iç kontrol modeli hakkında bilgi verilecektir.

\section{1. İç Kontrol Sistemi}

Her işletme amaç ve hedeflerine ulaşabilmek için bazı kontrol sistemleri oluşturur ve işletmelerin yönetilebilmesi için en temel fonksiyonlarından biri de kontroldür. İşletmelerin bu en temel fonksiyonlarından olan kontrol; iç kontrol sistemi aracılığıyla sağlanmaktadır. İç kontrol; işletmenin faaliyetlerinin işletmenin misyon ve vizyonu ile uyumlu ve verimli bir şekilde yürütülmesi, hata ve hilelerin tespit edilerek ortaya çıkmasının engellenmesi, finansal varlıkların korunması, 
muhasebe kayıtlarının eksiksiz, doğru olması ve finansal tabloların zamanında hazırlanması gibi hedeflere ulaşılması amacıyla oluşturulmuş olan tüm yöntem ve usullerdir (Bakkal ve Kasımoğlu, 2012: 1).

Günümüzde her geçen gün işletmelerin büyümesi, faaliyetlerinin artması ve karmaşıklaşması, hataların azaltılması veya giderilmesi, gelir ve giderlere sebep olan unsurların saptanması, güvenilir olan verilerin toplanması işletme yönetimleri için zorunluluk olmuştur (Gönen, 2007: 12). Bu zorunluluk, işletmelerin tüm süreçlerine odaklanan ve risklerini kontrol eden bir iç kontrol sisteminin kurulmasinı gerektirmektedir.

Yapılan bu tanımlar çerçevesinde iç kontrol sisteminin amaçları şu şekilde ifade edilebilir:

- İşletmenin varlıklarının korunması,

- $\quad$ Elde edilen bilgilerin doğruluk ve güvenilirliğinin sağlanması,

- İşletmenin faaliyetlerinin yasalara, politikalara, prosedürlere uygunluğunun sağlanması,

- İşletmenin kaynaklarında etkin ve verimli kullanılma sağlanması,

- İşletmenin belirlemiş olduğu amaç ve hedeflere ulaşılmasının sağlanmasıdır (Ceyhan ve Apan, 2014: 180).

İç kontrol sisteminin iyi kurulamadığı veya hiç olmadığı işletmelerde; yönetimin eksik ya da hatalı kararlar alması, işletme varlıklarında kayıpların yaşanması, işletmeyle ilgili usulsüzlüklerin yaşanması, işletmenin kar ve verimliliğinde azalışların yaşanması gibi durumların ortaya çıkacağı bilinmektedir (Fidan, Mumcu, 2019: 63). 2005: 38):

Başarılı bir iç kontrol sistemi için aşağıdaki ilkelerin dikkate alınması gerekmektedir (Kertiş,

- Görevlerin ayrımı ilkesi

- Kıymet hareketlerinin yetkilendirilmiş olması ilkesi

- Uygun belgeleme ve muhasebe kayıt düzeninin varolması ilkesi

- Varlıkların ve muhasebe kayıtlarının fiziken korunması ilkesi

- Bağımsız mutabakatın yapılması ilkesi

\subsection{COSO İç Kontrol Modeli}

Dünyada iç kontrole yönelik farklı modeller geliştirilmiştir. Bunlar; COSO, eSAC, CobiT ve SysTrust şeklindedir. COSO (Comitte of Sponsoring Organizations: Sponsor Kuruluşlar Komitesi) tarafından geliştirilmiş olan iç kontrol modeli, 1992 yılında yayınlanmıştır. COSO komitesini oluşturan kuruluşlar arasında; AICPA (Amerikan Sertifikalı Kamu Muhasebecileri Enstitüsü), Amerikan Muhasebeciler Birliği (AAA), Uluslararası Finans Yöneticileri (FEI), İç Denetçiler Enstitüsü (IIA) ve Yönetim Muhasebecileri Enstitüsü (IMA) yer almıştır (Aksoy, 2005: 144). COSO modeli, diğer modellerle karşılaştırıldığında içerik anlamında en genişi ve işletmenin tamamını kapsayan bir yaklaşımdır.

COSO tarafindan işletmeler için başarılı bir iç kontrol sisteminin hazırlanmasına rehberlik etmesi amacıyla geliştirilen iç kontrol modelinde (Hacıhasanoğlu ve Kaya, 2018: 241) iç kontrolün tanımı şu şekilde yapılmıştır (Kurt ve Uçma Uysal, 2015: 204):

"İç kontrol genel anlamda bir kuruluşun yönetim kurulu, yöneticileri ve diğer personeli tarafından yönlendirilen ve finansal raporlamanın güvenilirliği, faaliyetlerin etkinliği ve verimliliği, yasa ve düzenlemelere uygunluk hedeflerine ulaşmada makul güvence sağlamak üzere tasarlanmış bir süreçtir".

İç kontrol modeli 2013 y1lında COSO tarafından güncellenmiş olup, güncellenen COSO`da (2013)'te iç kontrolün tanımında büyük değişiklikler yapılmamıştır. 2013 yılındaki bu güncellemede işletmelerin finansal raporlama üzerindeki riskleri de dikkate alarak iç kontrol sistemlerini 
geliştirmelerini sağlamak amacıyla iç kontrolün Sarbanes Oxley Yasası (SOX) 404. Madde ile uyumlaştırılması amaçlanmıştır (Kurt ve Uçma Uysal, 2015: 205):

İç kontrol, işletmenin en üst yöneticisinden en alt çalışanına kadar herkesi etkileyen bir süreç olup, COSO iç kontrol modelinin oluşturulması ve etkin işlemesine ilişkin önlemler alınmasında sorumluluk üst yönetime aittir (Ceyhan ve Apan, 2014: 181).

COSO modeline göre iç kontrol sisteminin; kontrol ortamı, risk değerlendirme, kontrol faaliyetleri, bilgi ve iletişim ve izleme olmak üzere beş temel bileşeni bulunmaktadır. İç kontrol sistemini oluşturan bu beş bileşen, COSO tarafından yayımlanan "İç Kontrol-Bütünleşik Çerçeve Raporu"nda da aynı şekilde yer almıştır (Aytaç, 2014: 19).

Kontrol Ortamı: İç kontrol sisteminde beş ana bileşenin temelini oluşturmaktadır. İç kontrol sistemin kurulup işletildiği ortamdır. Kontrol ortamı, bir işletmenin politika ve kullandığı yöntemleri belirleme, azaltma, arttırma gibi faktörlerin tümünü kapsayan ve işletmenin amaçlarını ve bu amaçlara ulaşılabilmesi için gerekli olan stratejileri belirleyen bir süreçtir. Kontrol ortamının kurulup tasarlanması üst yönetimin sorumluluğunda olduğu için iç kontrol sisteminin en önemli bileşenidir. Kontrol ortamı, iç kontrolün örgüt genelinde yürütülmesi için temel oluşturan birtakım standartlar, süreçler ve yapılardan oluşur. Güçlü bir kontrol ortamının en önemli göstergeleri: örgütün dürüstlüğe ve etik değerlere verdiği önem, yeterli gözetim süreçleri ve yapılarına sahip olunması, yetki ve sorumlulukların uygun bir şekilde dağıtılması, üst düzey bir yetkinlikle ve amaçlara ulaşmak konusunda güçlü bir hesap verebilirlik yaklaşımıdır (Cömert, 2015: 177).

Risk Değerlendirmesi: Örgütsel amaçların başarılmasında ve kurumsal hedeflerin gerçekleştirilmesinde ortaya çıkabilecek engel ve önemli risklerin tespit edilmesi, analiz edilmesi, yönetilmesi ve bu risklere karşı uygun önlemler alınması sürecidir. İşletmeler; yeni personel ve teknolojiler, hızlı büyüme, yeni ürünler ve faaliyetler, bilgi sisteminin değiştirilmesi ya da yenilenmesi, işletmenin yeniden yapılanması gibi durumlardan kaynaklı risklerle karşılaşabilirler. Hastanelerde de durum böyle olup, birtakım risklerle karşılaşılması mümkündür.

Risk değerlendirmesi sürecinde; sistemin güçlü ve zayıf yönleri belirlenmeli, analiz edilmeli, risk alanları belirlenmeli ve bu alanlarda kontrol faaliyetleri yoğunlaştırılmalıdır ve değişen şartlar sürekli takip edilerek gerekli görüldüğünde değişiklikler yapılmalıdır.

Risk değerlendirmesi, işletmelerin en tepe yönetiminden en alt çalışana kadar herkesin katıldığı bir süreçtir. Bu süreçte uygulanması gereken aşamalar ise şunlardır:

$>\quad$ Hedeflerin belirlenmesi,

$>\quad$ Olayların tanımlanması,

$>\quad$ Kabul edilebilir risk düzeyinin belirlenmesi,

$>\quad$ Risklere karşılık verilmesidir (Dursun ve Akın, 2019: 50).

Hastanelerde de karşılaşabilecek risklerin önceden görülerek, olası zararların önüne geçilmesi anlamında riskleri azaltacak ya da firsata dönüştürecek yönetim faaliyetleri geliştirilmelidir. Risk yönetimi faaliyetlerini aktif olarak sürdüren hastaneler, hasta ve çalışan güvenliği ile hizmet kalitesi sağlama çabasında olmayan hastanelere kıyasla bir adım önde olacaktır (Türk ve Çil Koçyiğit, 2020: $85)$.

Kontrol Faaliyetleri: Kurumun amaçlarına ulaşmasında karşıllaşabileceği risklerin minimum düzeye indirilmesi veya bu riskleri yok etmeye yönelik alınan önlemlerin bütünü, uygulanan politika ve prosedürlerdir. Kontrol faaliyetleri; kurumun maddi ve/veya maddi olmayan tüm faaliyetlerini kapsamakta ve risk değerlendirme faaliyetleriyle ilişkili olduğu göz önünde bulundurulmalıdır. Kontrol faaliyetleri aşağıdakileri kapsamaktadır (Gökçen ve Tipi, 2019: 156):

$>\quad$ Performansin gözden geçirilmesi,

$>\quad$ Kaynaklara, bilgiye erişim kontrolleri,

> Fiziksel kontroller (işletmenin varlıklarının fiziksel olarak korunması),

$>\quad$ Görevlerin ayrımıdır.

Bilgi ve İletişim: İşletmelerde iç kontrol sürecinin etkin yürütülebilmesi, amaçlanan başarıya ulaşabilmesinde bilgi ve iletişimin rolü oldukça önemlidir. Bu nedenle, işletme hem iç (bilginin 
işletmenin tümüne çapraz, yukarıdan aşağıda, aşağıdan yukarıya ulaşması) hem de dış (işletme dışındaki taraflara bilginin ulaşması) kaynaklara ulaşabilmek amacıyla aktif olarak kullanılabilen iletişim kanalları oluşturmalıdır. Bilgi ve iletişim bileşeni, elde edilen bilgileri diğer ilgililere dağıtır ve diğer ilgililerle koordineli olunmasını sağlar. Etkin bir bilgi sisteminde her türlü bilginin zamanlı olarak kaydedilmesi, sınıflandırılması ve raporlanması ve sağlanmalıdır (Gökçen ve Tipi, 2019: 156).

İzleme: $\mathrm{Bu}$ bileşen, uygulanan iç kontrol sisteminin başarısı, kalitesi, kontrollerin işleyişi, alınması gereken önlemlerin belirlenmesi, uygun kontrol prosedürlerinin oluşturulmasından oluşan bir süreçtir. Zamanla etkinliğini azaltan ya da kaybeden iç kontrol sitemi prosedürlerinin yerine yenisinin oluşturulması ve uygulanması sürecinde de izleme bileşeni kendini göstermektedir. İzleme bileşeni aynı zamanda, işletmenin performans düzeyini denetleyen bir süreçtir ve bu süreç iç denetim tarafından gerçekleşmektedir. İzleme süreci; sürekli izleme ve ayrı ayrı değerlendirmelerden oluşabileceği gibi bu iki yöntemin birlikte kullanılmasından da oluşabilir. Ancak uygulanacak olan her iki yöntemde de; oluşan değişikliklerin yapısı ve riskleri ve kontrolleri yürüten çalışanların yetenekleri ve becerisi dikkat edilmesi gereken unsurlardır (Gökçen ve Tipi, 2019: 157).

\section{HASTANELERDE İÇ KONTROL SISTEMI}

Diğer tüm işletmelerde olduğu gibi ister küçük isterse büyük bir hastane olsun, işler, etkin ve verimli bir iç kontrol sisteminin oluşturulması karşılaşılabilecek risklerin en aza indirilmesi anlamında büyük önem arz eder. Sağlık hizmetleri işletmelerinin diğer işletmelerden farklı bir yapıya ve kendilerine özgü niteliklere sahip olmalarından dolayı, iç kontrol sistemi de diğer işletmelere göre önemini daha da artırmaktadır. Bunun nedeni, sağlık işletmeleri faaliyetlerinin aşağıdaki özelliklerinden kaynaklanmaktadır (Dursun ve Akın, 2019: 51): sağlığıyla ilgilidir.

- Sağl1k işletmelerinin faaliyet konusu ve sağlık işletmelerinde üretilen hizmet insan

- $\quad$ Her hastada farklı ilaç, tanı ve tedavi gerektiğinden ürün ve hizmet tanımı zor yapılır.

- $\quad$ Üretilen hizmetler stoklanamaz, kısa vadede olan değişimlere ayak uydurmak güçleşir, hizmete olan talebin artış ve azalışları değişkenlik gösterir.

- $\quad$ Verilen hizmetler uzmanlaşma gerektirdiğinden nitelikli personellere ve hizmetlere ihtiyaç duyulur, böylece maliyetler artar.

- $\quad$ Kullanılan makine ve cihazlar, ilaç ve sarf malzemelerin çeşitli olması yüksek yatırım sermayesi gerektirmektedir.

Yukarıda sayılan bu nedenlerden dolayı hastanelerde hata, hile ve risklerin hastane organizasyon yapılarında daha çok yer almasına sebebiyet verebilmektedir. Bütün bunlardan dolayı da sağlık kurumlarında da oldukça etkili ve her çalışanı içine alan bir iç kontrol sistemi kurulmalıdır.

Hastanelerde iç kontrol sisteminin kurulması; hastanenin varlıklarının korunması, hastane yönetiminde ve sağlı hizmetlerinde etkinliğin ve verimliliğin sağlanması, doğru ve güvenilir mali raporlama yapılması, hastane faaliyetlerinde yasa ve düzenlemelere uyulmasının sağlanması amacına hizmet eder (Dursun ve Akın, 2019: 5).

\section{LITERATÜR TARAMASI}

Literatüre bakıldığında hastane işletmeleri de dahil olmak üzere farklı sektördeki işletmelerde COSO iç kontrol modeliyle ilgili yapılan çalışmaların bazılarına aşağıda yer verilmiştir.

Ceyhan ve Apan (2014) çalışmalarında; COSO iç kontrol modeli bileşenleri arasındaki ilişkiyi ortaya koymayı amaçlamış ve bu doğrultuda, anket yöntemiyle özel bir hastanede doktor, hasta danışmanı, yönetici, hemşire, sağlık memuru, sağlık destek personeli gibi farklı meslek gruplarında yer alan personellerin iç kontrolle ilgili düşüncelerini belirlemeye çalışmışlardır. Elde dilen veriler, faktör analizi ve yapısal eşitlik modeliyle analiz edilmiştir. Analiz sonuçlarına göre; COSO iç kontrol bileşenleri arasında anlamlı ve pozitif yönlü bir ilişki olduğu görülmüştür. Böylece araştırma için geliştirilmiş olan hipotezlerin hepsi kabul edilmiştir.

Hacıhasanoğlu ve Kaya (2018) çalışmalarında üretim işletmelerinde iç kontrol sistemlerinin $\mathrm{COSO}$ iç kontrol bileşenlerine göre değerlendirmeyi ve bu bileşenlere uyum derecesini belirlemeyi amaçlamışlardır. Bunun yanı sıra; pazarlama çevresi, personel sayısı ve şirketin türü değişkenleri bazında verilen cevapların farklılaşıp farklılaşmadığı ve eğer farklılık varsa bu farklılıkların iç kontrol 
modelinin alt boyutları açısından ortaya koyulması da amaçlanmıştır. Bu amaç doğrultusunda; Kocaeli ilinin organize sanayi bölgelerinde faaliyet gösteren üretim işletmeleri çalışmaya dahil edilmiştir ve anket yöntemiyle nice araştırma olarak yapılmıştır. Elde edilen verilere göre; şirketin türü, personel sayısı ve pazarlama çevresi açısından COSO iç kontrol modelin bileşenlerinin değerlendirmesinde farklılıkların ortaya çıktığı görülmüştür ve oluşturulmuş olan hipotezler kabul edilmiştir.

Kara (2018) çalışmasında; iç kontrolün beş bileşeni çerçevesinde kalite yönetim sistemi bulunan işletmeler ile bulunmayan işletmelerin etkinliğini değerlendirmeyi amaçlamıştır. Bu amaç doğrultusunda, Van ve Malatya ilinde yer alan ve iç kontrol sistemi bulunan 275 işletme araştırmaya dahil olmuş ve anket yöntemiyle araştırma gerçekleştirilmiştir. Elde edilen verilere göre yapılan analiz sonuçlarına göre; kalite yönetim sistemi bulunan işletmeler ile kalite yönetim sistemi bulunmayan işletmelerin iç kontrol sistemi ve bileşenleri arasında anlamlı bir farklılık olduğu sonucuna ulaşılmıştır. Kalite yönetim sistemi belgesine sahip olan işletmelerde iç kontrol sisteminin daha etkin olduğu görülmüştür.

Dursun ve Akın (2019)'ın çalışmalarında; özel hastanelerin iç kontrol sistemini nasıl kurabileceği ve faaliyetlerini yaparken hangi iç kontrol sistemini yöntemlerine göre uygulama yaparsa iç kontrolle ilgili hedeflerine ulaşabileceği sorularının yanıtlamak amaçlanmıştır. Bu amaca yönelik nitel bir araştırma yapılmış olup özel hastanelerdeki iç kontrol modeli bileşenlerinin (kontrol ortamı, risk değerlendirme, kontrol faaliyetleri, bilgi ve iletişim ve izleme) önemi anlatılmıştır. Araştırmanın sonucunda; özel hastanelerin de faaliyetlerini yürütürken meydana gelebilecek olumsuzlukları önlemek için etkin bir iç kontrol sitemine sahip olması gerektiği belirtilmiştir.

Kurnaz (2019) çalışmasında; hastane işletmelerindeki iç kontrol sisteminin COSO iç kontrol modeli bileşenleri açısından incelenip değerlendirilmesi ve bu bileşenlere uyum derecesi ile hastane personellerinin söz konusu bileşenlerle ilgili değerlendirmelerinin meslek grupları açısından farklılaşıp farklılaşmadığının ortaya koyulmasını amaçlamışırı. Bu amaç doğrultusunda; bir kamu hastanesinde çalışan doktor, hemşire, hasta danışmanı, idari personel gibi farklı meslek gruplarını kapsayan ve bu personellere anket yöntemi uygulanarak elde edilen verilerle nicel bir araştırma yapılmıştır. Araştırma sonucunda elde edilen bulgulara göre araştırma yapılan hastanede COSO iç kontrol modeli bileşenlerinin hepsi ayrı ayrı incelenmiş olup sonuçlar şu şekildedir; kontrol ortamı bileşeni ile uyumlu bir kontrol ortamının olmadığı, risk değerlendirme bileşenine baktı̆̆ımızda bu bileşenin etkin olmadığı, kontrol faaliyetlerinin tamamen olmasa da kısmen uyumlu olduğu, bilgi ve iletişim faaliyetlerinin de kısmen uyumlu olduğu ve son olarak izleme bileşeni ile hastane işletmesinin uyumlu olduğu görülmüştür.

\section{ARASTTIRMANIN METODOLOJISI}

\subsection{Araştırmanın Amacı}

$\mathrm{Bu}$ araştırmada, hastane işletmelerindeki iç kontrol sisteminin COSO modeli bileşenleri çerçevesinde bu bileşenlere uyum derecesinin çalışanlarca değerlendirilmesinin ortaya konulması amaçlanmıştır. Ayrıca bu değerlendirmelerin farklı direktörlüklerde çalışanlarca farklılaşıp farklılaşmadığını ortaya koymak ta çalışmanın diğer amacıdır. Bu amaçla birden fazla şubesi bulunan özel bir hastanede anket uygulaması yapılmıştır.

\subsection{Araştırmanın Kısıtları}

Araştırma, özel bir hastane işletmesinin genel müdürlük çalışanları ile sınırlıdır. Hastane işletmesinin birden fazla şubesi bulunması nedeniyle idari personelinin ayrı bir genel müdürlük binasında olması ve dünyada yaşanan COVID-19 salgını nedeniyle sadece bu çalışanlar kapsama dahil edilebilmiştir. Ayrıca araştırmada kullanılan anket formuna katılımcıların sübjektif olarak vermiş olduğu cevaplara göre değerlendirme yapılmıştır. $\mathrm{Bu}$ nedenle elde edilen sonuçlar, tüm sağlik işletmeleri ve tüm hastane çalışanları geneline yaymak mümkün olmayacaktır.

\subsection{Araştırmanın Yöntemi ve Kapsamı}

Araştırma özel bir hastanede çalışan idari personellerini (muhasebe, insan kaynakları, satın alma, kalite, özlük işleri, bilgi işlem, kurumsal iletişim, medikal muhasebe, finans, uluslararası 
ilişkiler, anlaşmalı kurumlar birim çalışanları) kapsamaktadır. Araştırmanın yapıldığı Aralık 2020 tarihinde, alınan bilgiye göre, araştırma kapsamında yaklaşık 80 kişi bulunmaktadır. Araştırmanın evrenini oluşturan 80 kişinin 58'inden geçerli bir geri dönüş alınarak çalışmaya dahil edilmiştir. Örneklemin evreni temsil ettiğinin göstergesi olarak aşağıdaki formül kullanılmıştır (Yamane, 2001).

$$
n=\frac{N z^{2} p q}{N d^{2}+z^{2} p q}
$$

Bu formül ele alınarak, \%93 güvenirlik ve 0,50 olayın görülme sıklığı ile gerekli örneklem sayısının 54 olması yeterlidir.

Araştırmada veriler yüz yüze anket yöntemi ile elde edilmiştir. Çalışmada Kurnaz (2020)'ın Aksoy (2005), COSO (2013) ve Hacıhasanoğlu ve Kaya (2018)'nın yapmış oldukları çalışmalardan yararlanarak hazırlamış olduğu anket formu kullanılmıştır. Anket formu; iç kontrol modeli bileşenleri çerçevesinde iç kontrol sisteminin değerlendirilmesine ilişkin sorulardan oluşmakta olup, 5'li likert ölçeğine göre hazırlanmıştır. Birim bazında uygulanan anket sonuçları, personellerin çalıştıkları birimlerin bağlı oldukları direktörlük açısından değerlendirilmiştir.

Anketlerden elde edilen veriler için öncelikle güvenilirlik analizi yapılmış, ardından da istatistiksel programlar aracıllı̆ıyla ortalama ve standart sapma değerleri hesaplanmıştır. Hipotezlerin test edilmesinde de normal dağılım gösteren risk değerlendirme alt boyutunda Anova Testi, normal dağılım göstermeyen diğer alt boyutlarda ise Kruskal-Wallis H Testi kullanılmıştır. Sözkonusu testlerin anlamlılık düzeyi 0,05 olarak baz alınmıştır.

\subsection{Araştırmanın Hipotezleri}

Araştırmanın amacı doğrultusunda oluşturulmuş olan hipotezler şunlardır:

H1: Katılımcıların kontrol ortamı bileşenine yönelik değerlendirmeleri bağlı oldukları direktörlük gruplarına göre farklılaşmaktadır.

H2: Katılımcıların risk değerlendirme bileşenine yönelik değerlendirmeleri bağlı oldukları direktörlük gruplarına göre farklılaşmaktadır.

H3: Katılımcıların kontrol faaliyetleri bileşenine yönelik değerlendirmeleri bağlı oldukları direktörlük gruplarına göre farklılaşmaktadır.

H4: Katılımcıların bilgi ve iletişim bileşenine yönelik değerlendirmeleri bağlı oldukları direktörlük gruplarına göre farklılaşmaktadır.

H5: Katılımcıların izleme bileşenine yönelik değerlendirmeleri bağlı oldukları direktörlük gruplarına göre farklılaşmaktadır.

\subsection{Güvenilirlik Analizi} sunulmuştur.

Bileşenlere ilişkin olarak Cronbach's Alfa güvenilirlik analizi sonuçları Tablo 1'de

Tablo 1: Güvenilirlik Analiz Sonuçları

\begin{tabular}{|l|c|c|}
\hline COSO Bileşeni & İfade Sayısı & Cronbach's Alfa \\
\hline "Kontrol Ortamı" & 22 & 0,911 \\
\hline "Risk Değerlendirme" & 14 & 0,920 \\
\hline "Kontrol Faaliyetleri" & 11 & 0,890 \\
\hline "Bilgi ve İletişim" & 9 & 0,907 \\
\hline "İzleme" & 5 & 0,905 \\
\hline
\end{tabular}

Tablo 1'den de anlaşılacağı üzere, anket içerisinde yer alan ölçek ifadeleri yüksek düzeyde güvenilirdir. 
Sağlık Sektöründe Özel Bir Hastanenin COSO İ̧̧ Kontrol Modeli Bileşenleri Çerçevesinde Incelenmesi

\subsection{Normallik Analizi}

Çalışmada, anketin uygulanması sonucu elde edilmiş olan verilerin normal dağılım gösterip göstermediğinin tespitinde Shapiro-Wilk değerinin anlamlılık düzeyi sonuçları Tablo 2'deverilmiştir.

Tablo 2: Normallik Testi Sonuçları

\begin{tabular}{|l|c|c|c|}
\hline \multirow{2}{*}{} & \multicolumn{2}{|c|}{ Shapiro-Wilk } \\
\cline { 2 - 4 } & İstatistik & sd & 0,026 \\
\hline Kontrol Ortamı & 0,953 & 58 & 0,134 \\
\hline Risk Değerlendirme & 0,968 & 58 & 0,025 \\
\hline Kontrol Faaliyetleri & 0,953 & 58 & 0,030 \\
\hline Bilgi ve İletişim & 0,955 & 58 & 0,005 \\
\hline İzleme & 0,938 & 58 & p \\
\hline
\end{tabular}

Tablo 2'den de anlaşılacağı üzere $\mathrm{p}$ anlamlılık düzeyinin kontrol ortamı, kontrol faaliyetleri, bilgi ve iletişim ile izleme alt boyutlarında verilerin normal dağılım göstermediği, risk değerlendirme alt boyutunun ise normal dağılım gösterdiği görülmektedir. Bu nedenle, araştırmada normal dağılımın olmadığı durumda parametrik olmayan test yöntemi, normal dağılımın olduğu durumda ise parametrik test yöntemi kullanılmıştır.

\section{ARAŞTIRMA BULGULARI}

Araştırmaya katılan hastanenin idari personel çalışanlarının verileri ve araştırma kapsamındaki diğer bulguların değerlendirilmesi bu bölümde yapılmıştır.

\subsection{Katılımcıların Bağlı Bulundukları Direktörlüklere İlişkin Bulgular}

Araştırmaya katılan hastanenin idari personel çalışanlarının bağlı bulundukları direktörlüklere göre dağılımı aşağıda Tablo3'te sunulmuştur.

Tablo 3: Katılımcıların Direktörlük Gruplarına Göre Dağılımları

\begin{tabular}{|l|c|c|}
\hline \multicolumn{1}{|c|}{ Direktörlük } & N & \% \\
\hline $\begin{array}{l}\text { Operasyon Hizmetleri Direktörlüğ̈̈ (Satınalma, Bilgi İşlem ve } \\
\text { Medikal Muhasebe birimleri) }\end{array}$ & 25 & 43,10 \\
\hline Mali İşler Direktörlüğü (Muhasebe, Finans ve Özlük İşleri birimleri) & 14 & 24,10 \\
\hline $\begin{array}{l}\text { Yönetim Hizmetleri Direktörlüğü (İnsan Kaynakları, Kalite ve Hasta } \\
\text { Deneyimi birimleri) }\end{array}$ & 11 & 19,00 \\
\hline $\begin{array}{l}\text { İş Geliştirme ve Proje Direktörlüğü (Kurumsal İletişim ve Marka, } \\
\text { Anlaşmalı Kurumlar ve Uluslararası İlişkiler birimleri) }\end{array}$ & 8 & 13,80 \\
\hline
\end{tabular}

Tablo 3’te katılımcıların direktörlük gruplarına göre dağılımına bakıldığında; en çok Operasyon Hizmetleri Direktörlüğünün (\%43,10'luk bir oranla); en az da İş Geliştirme ve Proje Direktörlüğü’nün (\%13,80'lik bir oran) yer aldığı göze çarpmaktadır.

\subsection{COSO İç Kontrol Modeli Bileşenlerine Ait Bulgular}

Katılımcılar tarafından COSO modeli bileşenlerine ilişkin verilmiş olunan cevaplara ait ortalama ve standart sapma değerleri aşağıda sunulmuştur.

Analiz sonucu oluşan ortalama değer aralıklarının yorumlanmasında aşağıdaki sınıflama baz alınmıştır (Özgan ve Akıncı: 2011).

$\begin{array}{ll}1,00-1,80 & \text { Çok Düşük } \\ 1,81-2,60 & \text { Düşük } \\ 2,61-3,40 & \text { Orta }\end{array}$


Sağlık Sektöründe Özel Bir Hastanenin COSO İ̧̧ Kontrol Modeli Bileşenleri Çerçevesinde Incelenmesi
$3,41-4,20$
Yüksek
$4,21-5,00$
Çok Yüksek

Tablo 4: "Kontrol Ortamı” Bileşenine Yönelik İfadelere Ait Ortalama ve Standart Sapmalar

\begin{tabular}{|c|c|c|}
\hline İfadeler & Ort. & SS \\
\hline "Kurumda, İç Kontrol Standartları bilinmektedir." & 3,78 & 1,093 \\
\hline $\begin{array}{l}\text { "Kurumda, iç kontrol sistemine ilişkin yönetici ve personelin farkındalık ve sahiplenilmesini } \\
\text { arttırmaya yönelik faaliyetler yapılmaktadır." }\end{array}$ & 3,69 & 1,079 \\
\hline $\begin{array}{l}\text { "Kurumda, her düzeydeki personele etik davranış ilkeleri ve bu ilkelere ilişkin sorumlulukları } \\
\text { hakkında bilgilendirme yapılmaktadır." }\end{array}$ & 3,91 & 0,904 \\
\hline $\begin{array}{l}\text { "Kurumda, her düzeydeki personele etik dışı davranış durumunda uygulanacak yaptırımlar hakkında } \\
\text { bilgilendirme yapılmaktadır." }\end{array}$ & 3,78 & 0,796 \\
\hline $\begin{array}{l}\text { "Kurumda, vatandaşa sunulan hizmetlerle ilgili süre ve yöntem konusunda bir standart } \\
\text { geliştirilmiştir." }\end{array}$ & 3,98 & 0,783 \\
\hline $\begin{array}{l}\text { "Kurumda, tüm iş süreçleri ile ilgili çıktılara personelin ve yetkili mercilerin erişimleri } \\
\text { sağlanmaktadır." }\end{array}$ & 4,12 & 0,818 \\
\hline $\begin{array}{l}\text { "Kurumda, personelin ve kurumdan hizmet alanların öneri ve şikâyetlerin bildirebilecekleri uygun } \\
\text { mekanizmalar bulunmaktadır." }\end{array}$ & 3,97 & 1,025 \\
\hline "Kurumda, görev tanımlarına yönelik bir düzenleme (yönerge, genelge, vb.) yapılmaktadır." & 4,24 & 0,823 \\
\hline "Kurumda, her düzeydeki çalışanlara görev tanımları yazılı olarak bildirilmektedir." & 4,07 & 0,792 \\
\hline $\begin{array}{l}\text { "Kurumda, organizasyon şeması görev dağılımını, hesap vermeye uygun raporlama kanallarını } \\
\text { göstermektedir." }\end{array}$ & 3,93 & 0,896 \\
\hline "Kurumda, alt birimlerin görevleri, idarenin ve birimlerin misyonu ile uyumludur." & 3,93 & 0,746 \\
\hline "Kurumda, hassas görevler ve bu görevlere ilişkin prosedürler belirlenmiştir." & 3,78 & 0,992 \\
\hline $\begin{array}{l}\text { "Kurumda, her düzeydeki yöneticinin, verilen görevlerin sonucunu izlemesini sağlayacak } \\
\text { mekanizmalar oluşturulmuştur." }\end{array}$ & 3,66 & 1,052 \\
\hline $\begin{array}{l}\text { "Kurumda, her görev için gerekli eğitim ihtiyacı belirlenerek, bu ihtiyacı giderecek eğitim faaliyetleri } \\
\text { düzenli olarak yapılmaktadır." }\end{array}$ & 3,74 & 1,101 \\
\hline $\begin{array}{l}\text { "Kurumda, yöneticiler personelin yeterliliği/performansı ile ilgili yaptıkları değerlendirmeleri ilgili } \\
\text { personelle paylaşmaktadır." }\end{array}$ & 3,38 & 1,105 \\
\hline $\begin{array}{l}\text { "Kurumda, performansı yetersiz bulunan personelin performansını geliştirmeye yönelik önlemler } \\
\text { alınmaktadır." }\end{array}$ & 3,59 & 2,676 \\
\hline "Kurumda yüksek performans gösteren personel için ödüllendirme mekanizmaları bulunmaktadır." & 2,98 & 1,084 \\
\hline $\begin{array}{l}\text { "Kurumda, insan kaynakları ile ilgili prosedürler (personel alımı, yer değiştirme, vb.) } \\
\text { bulunmaktadır." }\end{array}$ & 3,98 & 0,982 \\
\hline "Kurumda, iş akış süreçlerinde imza ve onay mercileri belirlenmiştir." & 4,12 & 0,880 \\
\hline "Kurumda, yapılacak yetki devirlerinin esasları yazılı olarak belirlenmiştir." & 3,91 & 0,884 \\
\hline "Kurumda, yetki devredilecek personel için asgari gereklilikler (bilgi, deneyim, vb.) belirlenmiştir." & 3,84 & 0,768 \\
\hline $\begin{array}{l}\text { "Kurumda, yetki devredilen personelin, yetkinin kullanımına ilişkin olarak belli dönemlerde yetki } \\
\text { devredene rapor vermesine ilişkin düzenlemeler bulunmaktadır." }\end{array}$ & 3,45 & 1,046 \\
\hline
\end{tabular}

COSO iç kontrol modeli bileşenleri içerisinde yer alan kontrol ortamı bileşenine yönelik değerlendirmelere ait ortalama ve standart sapma değerlerine bakıldığında;

en yüksek düzeyli katılımın; "kurumda, görev tanımlarına yönelik bir düzenleme (yönerge, genelge, vb.) yapılmaktadır" ( $\overline{\mathrm{X}}=4,24)$ ifadesine; 
en düşük düzeyli katılımın ise; "kurumda yüksek performans gösteren personel için ödüllendirme mekanizmaları bulunmaktadır" $(\bar{X}=3,97)$ ifadesine

ilişkin olduğu ortaya çıkmıştır.

Tablo 5: “Risk Değerlendirme” Bileșenine Yönelik İfadelere Ait Ortalama ve Standart Sapmalar

\begin{tabular}{|c|c|c|}
\hline İfadeler & Ort. & SS \\
\hline $\begin{array}{l}\text { "Kurumda, yürütülen faaliyetlerin stratejik plan ve performans programıla belirlenen amaç ve } \\
\text { hedeflere uyumunu sağlamaya yönelik bir prosedür vardır." }\end{array}$ & 3,97 & 2,609 \\
\hline "Kurumda, üst yönetici tarafından onaylanmış risk strateji belgesi tüm çalışanlara duyurulmaktadır." & 3,66 & 0,909 \\
\hline $\begin{array}{l}\text { "Kurumda, risk yönetimine ilişkin görev ve sorumluluklar açık bir şekilde ve yazılı olarak } \\
\text { belirlenmektedir." }\end{array}$ & 3,40 & 1,091 \\
\hline "Kurumda, risklerin tespiti operasyonel düzeyde yapılmaktadır." & 3,45 & 0,994 \\
\hline "Kurumda, tespit edilen risklerin, muhtemel etkileri ve gerçekleşme olasıllkları ölçülmektedir." & 3,59 & 0,918 \\
\hline "Kurumda, tespit edilen riskler önem derecelerine göre önceliklendirilmektedir.” & 3,64 & 0,892 \\
\hline "Kurumda, tespit edilen riskler kayıt altına alınmaktadır." & 3,67 & 0,886 \\
\hline "Kurumda, tespit edilen risklere verilecek cevaplar belirlenirken fayda-maliyet analizi yapılır." & 3,64 & 0,873 \\
\hline $\begin{array}{l}\text { "Kurumda, tespit edilen risklerin gecçekleşme olasılıklarında veya etkilerinde bir değişiklik olup } \\
\text { olmadığı ya da yeni risklerin ortaya çıkıp çımadığı belirli periyotlarla gözden geçirilmektedir." }\end{array}$ & 3,52 & 0,922 \\
\hline "Kurumda, risk yönetimi sürecinde personelin katkısı dikkate alınmaktadır." & 3,67 & 0,944 \\
\hline "Kurumda, çalışanlar risk yönetimine ilişkin görev ve sorumluluklarının bilincindedir." & 3,50 & 0,978 \\
\hline $\begin{array}{l}\text { "Kurumda, diğer birimlerle ortak yürütülmesi gereken risklerin bulunması durumda söz konusu } \\
\text { risklerin yönetilmesine ilişkin olarak ilgili birim ile gerekli iş birliği yapılmaktadır." }\end{array}$ & 3,57 & 0,975 \\
\hline "Kurumda, risk yönetiminden elde edilen deneyimler diğer birimlerle paylaşılmaktadır." & 3,74 & 0,909 \\
\hline "Kurt & 3,66 & 0,947 \\
\hline
\end{tabular}

COSO iç kontrol modeli bileșenleri içerisinde yer alan risk değerlendirme bileșenine yönelik değerlendirmelere ait ortalama ve standart sapma değerlerine bakıldığında;

en yüksek düzeyli katılımın; "kurumda, yürütülen faaliyetlerin stratejik plan ve performans programılla belirlenen amaç ve hedeflere uyumunu sağlamaya yönelik bir prosedür vardır" $(X=3,97)$ ifadesine;

en düşük düzeyli katılımın ise; "kurumda, risk yönetimine ilişkin görev ve sorumluluklar açık bir şekilde ve yazılı olarak belirlenmektedir" $(\overline{\mathrm{X}}=3,40)$ ifadesine ait olduğu ortaya çıkmıştır.

Tablo 6: "Kontrol Faaliyetleri” Bileşenine Yönelik İfadelere Ait Ortalama ve Standart Sapmalar

\begin{tabular}{|c|c|c|}
\hline İfadeler & Ort. & SS \\
\hline "Kurumda, her bir faaliyet ve riskler için etkin kontrol yöntemleri belirlenerek uygulanmaktadır." & 3,57 & 0,819 \\
\hline "Kurumda, kontrol faaliyetleri tespit edilirken fayda - maliyet analizi yapılmaktadır." & 3,50 & 0,941 \\
\hline "Kurumda, uygulanan kontrol faaliyetlerinin etkililiği düzenli olarak gözden geçirilmektedir." & 3,50 & 0,941 \\
\hline $\begin{array}{l}\text { "Kurumda, prosedürlerin etkili ve sürekli bir şekilde uygulanması için gerekli kontroller } \\
\text { yapılmaktadır." }\end{array}$ & 3,79 & 0,894 \\
\hline "Kurumda, görevler ayrılığı ilkesi uygulanmaktadır." & 3,69 & 0,922 \\
\hline $\begin{array}{l}\text { "Kurumda, olağanüstü durumlarda faaliyetlerin sürekliliğini etkileyebilecek durumlara karşı önlemler } \\
\text { alınmaktadır." }\end{array}$ & 3,74 & 0,828 \\
\hline "Kurumda, vekâlet sistemi etkin bir şekilde uygulanmaktadır." & 3,76 & 0,823 \\
\hline $\begin{array}{l}\text { "Kurumda, görevinden ayrılan personel yaptığı işle ilgili yeni görevlendirilen personele rapor } \\
\text { vermektedir." }\end{array}$ & 3,86 & 0,926 \\
\hline $\begin{array}{l}\text { "Kurumda, kullanılan bilgi sistemlerinin güvenliğini sağlamaya yönelik mekanizmalar } \\
\text { bulunmaktadır." }\end{array}$ & 4,12 & 0,860 \\
\hline
\end{tabular}


"Kurumda, bilgi sistemlerine veri girişi ile bunlara erişim konusunda yetkilendirmeler yapılmaktadir."

"Kurumda, bilgi sistemleri için yeterli bir yedekleme mekanizması ve teste tabi tutulmuş olağanüstü durum onarım planları mevcuttur."

4,16

COSO iç kontrol modeli bileşenleri içerisinde yer alan kontrol faaliyetleri bileşenine yönelik değerlendirmelere ait ortalama ve standart sapma değerlerine bakıldığında;

en yüksek düzeyli katılımın; "kurumda, bilgi sistemlerine veri girişi ile bunlara erişim konusunda yetkilendirmeler yapılmaktadır" $(\bar{X}=4,16)$ ifadesine;

en düşük düzeyli katılımın ise; "kurumda, kontrol faaliyetleri tespit edilirken fayda - maliyet analizi yapılmaktadır" ve "kurumda, uygulanan kontrol faaliyetlerinin etkililiği düzenli olarak gözden geçirilmektedir" ( $\overline{\mathrm{X}}=3,50)$ ifadelerine ait olduğu ortaya çıkmıştır.

Tablo 7: “Bilgi ve İletişim”" Bileşenine Yönelik İfadelere Ait Ortalama ve Standart Sapmalar

\begin{tabular}{|l|c|c|}
\hline \multicolumn{1}{|c|}{ İfadeler } & Ort. & SS \\
\hline "Kurumda, yatay ve dikey iletişimi kapsayan etkin bir iç iletişim sistemi bunulmaktadır." & 3,81 & 0,999 \\
\hline "Kurumda, dış paydaşlar ile etkin iletişimi sağlayacak bir dış iletişim sistemi bulunmaktadır." & 3,78 & 1,060 \\
\hline $\begin{array}{l}\text { "Mevcut iletişim sistemleri personelin veya dış paydaşların beklenti, öneri ve şikâyetlerini } \\
\text { iletmelerine imkân vermektedir." }\end{array}$ & 3,93 & 0,915 \\
\hline $\begin{array}{l}\text { "Kurumda, personele görev ve sorumlulukları kapsamında kendisinden neler beklendiği } \\
\text { bildirilmektedir." }\end{array}$ & 4,07 & 0,856 \\
\hline $\begin{array}{l}\text { "Mevcut bilgi sistemleri belirlenmiş hedeflerin izlenmesine ve bu doğrultuda gerçekleştirilen } \\
\text { faaliyetler üzerinde etkin bir değerlendirme yapılması imkân vermektedir." }\end{array}$ & 3,97 & 0,878 \\
\hline $\begin{array}{l}\text { "Kurumda, hangi raporların kim tarafından ne sıklıkta ne zaman hazırlanacağı kime sunulacağı ve } \\
\text { hazırlanan raporların kim tarafından kontrol edileceği açıça belirlenip personele bildirilmiştir." }\end{array}$ & 4,12 & 0,651 \\
\hline $\begin{array}{l}\text { "Kurumda, iş süreçlerinin kaydı, sınıflandırılması, korunması ve erişimini kapsayan belirlenmiş } \\
\text { standartlara uygun arşiv ve dokümantasyon sistemi bulunmaktadır.” }\end{array}$ & 4,09 & 0,756 \\
\hline $\begin{array}{l}\text { "Kurumda, personel kendisiyle ilgili yapılacak ihbar/şikâyetlere yönelik prosedürler hakkında } \\
\text { bilgilendirilmektedir." }\end{array}$ & 3,95 & 0,847 \\
\hline "Kurumda, ihbar/şikâyette bulunan kişinin güvenliğini sağlayıcı prosedürler bulunmaktadır.” & 3,86 & 0,888 \\
\hline
\end{tabular}

COSO iç kontrol modeli bileşenleri içerisinde yer alan bilgi ve iletişim bileșenine yönelik değerlendirmelere ait ortalama ve standart sapma değerlerine bakıldığında;

En yüksek düzeyli katılımın; "kurumda, hangi raporların kim tarafından, ne sıklıkta, ne zaman hazırlanacağı, kime sunulacağı ve hazırlanan raporların kim tarafından kontrol edileceği açıkça belirlenip personele bildirilmiştir" $(\bar{X}=4,12)$ ifadesine;

En düşük düzeyli katılımın ise; "kurumda, dış paydaşlar ile etkin iletişimi sağlayacak bir dış iletişim sistemi bulunmaktadır" ifadesine $(\overline{\mathrm{X}}=3,78)$ ait olduğu ortaya çıkmıştır.

Tablo 8: “İzleme” Bileşenine Yönelik İfadelere Ait Ortalama ve Standart Sapmalar

\begin{tabular}{|l|c|c|}
\hline \multicolumn{1}{|c|}{ İfadeler } & Ort. & SS \\
\hline $\begin{array}{l}\text { "Kurumda, iç kontrolün etkili bir şekilde işleyip işlemediği konusunda yöneticilere geri bildirimde } \\
\text { bulunmaya olanak sağlayacak toplantılar düzenlenmektedir." }\end{array}$ & 4,10 & 1,266 \\
\hline "Kurumda, denetim faaliyetleri etkin olarak uygulanmaktadır." & 3,93 &, 989 \\
\hline "Kurumda, iç kontrol sisteminin işleyişi belli periyotlarda değerlendirilmektedir.” & 3,95 &, 887 \\
\hline $\begin{array}{l}\text { "İç kontrolün değerlendirilmesinde, yöneticilerin görüşleri, kişi/kurumların talep ve şikâyetleri } \\
\text { dikkate alınmaktadır." }\end{array}$ & 3,95 &, 887 \\
\hline $\begin{array}{l}\text { "Kurumda, iç kontrolün değerlendirilmesi sonucunda alınması gereken önlemler belirlenip } \\
\text { uygulanmaktadır." }\end{array}$ & 4,00 &, 879 \\
\hline
\end{tabular}

COSO iç kontrol modeli bileşenleri içerisinde yer alan izleme bileşenine yönelik değerlendirmelere ait ortalama ve standart sapma değerlerine bakıldığında; 
En yüksek düzeyli katılımın; "kurumda, iç kontrolün etkili bir şekilde işleyip işlemediği konusunda yöneticilere geri bildirimde bulunmaya olanak sağlayacak toplantılar düzenlenmektedir" $(\overline{\mathrm{X}}=4,10)$ ifadesine;

En düşük düzeyli katılımın ise; "kurumda, denetim faaliyetleri etkin olarak uygulanmaktadır" ifadesine $(\overline{\mathrm{X}}=3,93)$ ait olduğu ortaya çıkmıştır.

Tablo 9: Tüm Alt Boyutların Ortalama ve Standart Sapma Sonuçları

\begin{tabular}{|l|c|c|c|c|c|}
\hline & Kontrol Ortamı & $\begin{array}{c}\text { Risk } \\
\text { Değerlendirme }\end{array}$ & $\begin{array}{c}\text { Kontrol } \\
\text { Faaliyetleri }\end{array}$ & Bilgi ve İletişim & İzleme \\
\hline Ortalama & 3,80 & 3,60 & 3,79 & 3,90 & 3,98 \\
\hline Standart Sapma & 0,982 & 0,872 & 0,890 & 1,060 & 1,014 \\
\hline \multicolumn{7}{|c|}{ Genel Ortalama: 3,81 } \\
Standart Sapma: 0,97
\end{tabular}

Tablo 9, katılımcıların iç kontrol modeli bileşenlerine ilişkin görüşlerin "ortalama ve standart sapma" değerlerini içermektedir. Buna göre; katılımcıların iç kontrol modeline ilişkin ifadelere katılım oranları genel olarak 3,81'dir. İç kontrol modeline ilişkin görüşler içerisinde en yükssek düzeyli katılımın "izleme" boyutunda iken, en düşük düzeyli katılımın ise "risk değerlendirme" boyutunda yer alan ifadelere ilişkin olduğu dikkati çekmektedir.

\subsection{Hipotez Testi Sonuçları}

Kurumda çalışıp ta ve araştırmaya dahil olan katılımcıların COSO bileşenlerine yönelik değerlendirmeler açısından, direktörlük grupları arasında anlamlı bir farklılık olmadığını ortaya koyabilmek amaciyla oluşturulan hipotezlerin test edilmesine yönelik bulgular aşağıdaki tablolarda verilmiştir. Hipotezlerin oluşturulmasında direktörlükler; yönetim, operasyon, iş geliştirme ve mali işler direktörlüğü olmak üzere dört gruba ayrılmıştır. Hipotezlerin test edilmesinde normal dağılımın olduğu tespit edilen "risk değerlendirme" alt boyutunda Anova Testi, normal dağılımın olmadığı diğer alt boyutlarda ise Kruskal-Wallis H Testi kullanılmıştır.

H1: Katılımcıların kontrol ortamı bileşenine yönelik değerlendirmeleri bağlı oldukları direktörlük gruplarına göre farklılaşmaktadır.

Tablo 10: Direktörlük Grupları Açısından “Kontrol Ortamı” Bileşenine Yönelik Değerlendirmelerin Farklılaşıp Farklılaşmadığını Ölçen Kruskal-Wallis H Testi Sonuçları

\begin{tabular}{|c|c|c|c|c|c|}
\hline & Birim & $\mathbf{N}$ & $\begin{array}{c}\text { Siralı } \\
\text { Ortalama }\end{array}$ & $\begin{array}{l}\text { Kruskal- } \\
\text { Wallis H }\end{array}$ & $\mathbf{p}$ \\
\hline \multirow[t]{5}{*}{ Kontrol Ortamı } & İş Geliştirme ve Pazarlama & 8 & 27,56 & \multirow[t]{5}{*}{1,474} & \multirow[t]{5}{*}{0,69} \\
\hline & Mali İşler Direktörlüğü & 14 & 33,64 & & \\
\hline & Yönetim Hizmetleri Direktörlüğü & 11 & 25,82 & & \\
\hline & Operasyon Hizmetleri Direktörlüğü & 25 & 29,42 & & \\
\hline & Toplam & 58 & & & \\
\hline
\end{tabular}

Birim ile kontrol ortamı bileşenine yönelik görüşler arasındaki farklılığın olup olmadığını tespit etmeye yönelik yapılan analiz sonucunda, anlamlı bir farklılık olmadığı tespit edilmiştir.H1 hipotezi reddedilmiştir. Biriminin kontrol ortamı bileşenine yönelik görüşler üzerinde herhangi bir etkisinin olmadığı söylenebilir.

H2: Katılımcıların risk değerlendirme bileşenine yönelik değerlendirmeleri bağlı oldukları direktörlük gruplarına göre farklılaşmaktadır. 
Sağlık Sektöründe Özel Bir Hastanenin COSO İ̧̧ Kontrol Modeli Bileşenleri Çerçevesinde Incelenmesi

Tablo 11: Direktörlük Grupları Açısından “Risk Değerlendirme” Bileşenine Yönelik Değerlendirmelerin Farklılaşıp Farklılaşmadığını Ölçen Anova Testi Sonuçları

\begin{tabular}{|c|c|c|c|c|c|c|}
\hline & Birim & $\mathbf{N}$ & Ort. & SS & $\mathbf{F}$ & $\mathbf{P}$ \\
\hline \multirow{5}{*}{$\begin{array}{l}\text { Risk } \\
\text { Değerlendirme }\end{array}$} & İş Geliştirme ve Pazarlama & 8 & 3,61 & 0,557 & \multirow[t]{5}{*}{0,734} & \multirow[t]{5}{*}{0,54} \\
\hline & Mali İşler Direktörlüğü & 14 & 3,75 & 1,070 & & \\
\hline & Yönetim Hizmetleri Direktörlüğü & 11 & 3,31 & 0,867 & & \\
\hline & Operasyon Hizmetleri Direktörlüğü & 25 & 3,69 & 0,666 & & \\
\hline & Toplam & 58 & 3,62 & 0,802 & & \\
\hline
\end{tabular}

Birim ile risk değerlendirme bileşenine yönelik görüşler arasındaki farklılığın olup olmadığını tespitin etmeye yönelik yapılan analiz sonucunda, anlamlı bir farklılık olmadığ 1 tespit edilmiştir. H2 hipotezi reddedilmiştir. Biriminin risk değerlendirme bileşenine yönelik görüşler üzerinde herhangi bir etkisinin olmadığı söylenebilir.

H3: Katılımcıların kontrol faaliyetleri bileşenine yönelik değerlendirmeleri bağlı oldukları direktörlük gruplarına göre farklılaşmaktadır.

Tablo 12: Direktörlük Grupları Açısından “Kontrol Faaliyetleri” Bileşenine Yönelik Değerlendirmelerin Farklılaşıp Farklılaşmadığını Ölçen Kruskal-Wallis H Testi Sonuçları

\begin{tabular}{|l|l|r|r|r|c|}
\hline & Birim & N & \multicolumn{1}{|c|}{$\begin{array}{c}\text { Siralı } \\
\text { Ortalama }\end{array}$} & $\begin{array}{c}\text { Kruskal- } \\
\text { Wallis H }\end{array}$ & p \\
\hline $\begin{array}{l}\text { Kontrol } \\
\text { Faaliyetleri }\end{array}$ & İş Geliştirme ve Pazarlama & 8 & 32,38 & 2,777 & 0,43 \\
\cline { 2 - 4 } & Mali İşler Direktörlüğü & 14 & 33,04 \\
\cline { 2 - 4 } & Yönetim Hizmetleri Direktörlüğü & 11 & 22,45 \\
\cline { 2 - 4 } & Operasyon Hizmetleri Direktörlüğü & 25 & 29,70 \\
\cline { 2 - 5 } & Toplam & 58 & & \\
\end{tabular}

Birim ile kontrol faaliyetleri bileşenine yönelik görüşler arasındaki farklılığın olup olmadığını tespit etmeye yönelik yapılan analiz sonucunda, anlamlı bir farklılık olmadığı tespit edilmiştir.H3 hipotezi reddedilmiştir. Biriminin kontrol faaliyetleri bileşenine yönelik görüşler üzerinde herhangi bir etkisinin olmadığ 1 söylenebilir.

H4: Katılımcıların bilgi ve iletişim bileşenine yönelik değerlendirmeleri bağlı oldukları direktörlük gruplarına göre farklılaşmaktadır.

Tablo 13: Direktörlük Grupları Açısından “Bilgi ve İletişim” Bileşenine Yönelik Değerlendirmelerin Farklılaşıp Farklılaşmadığını Ölçen Kruskal-Wallis H Testi Sonuçları

\begin{tabular}{|l|l|r|r|r|c|}
\hline & Birim & N & $\begin{array}{c}\text { Siralı } \\
\text { Ortalama }\end{array}$ & $\begin{array}{c}\text { Kruskal- } \\
\text { Wallis H }\end{array}$ & p \\
\hline \multirow{3}{*}{ Bilgi ve İletişim } & İş Geliştirme ve Pazarlama & 8 & 27,75 & \multirow{2}{*}{3,195} & 0,36 \\
\cline { 2 - 4 } & Mali İşler Direktörlüğü & 14 & 31,71 \\
\cline { 2 - 4 } & Yönetim Hizmetleri Direktörlüğü & 11 & 21,91 \\
\cline { 2 - 4 } & Operasyon Hizmetleri Direktörlüğü & 25 & 32,16 & \\
\cline { 2 - 4 } & Toplam & 58 & & \\
\end{tabular}

Birim ile bilgi ve iletişim bileşenine yönelik görüşler arasındaki farklılığın olup olmadığını tespit etmeye yönelik yapılan analiz sonucunda, anlamlı bir farklılık olmadığ 1 tespit edilmiştir.H4 hipotezi reddedilmiştir. Biriminin bilgi ve iletişim bileşenine yönelik görüşler üzerinde herhangi bir etkisinin olmadığı söylenebilir.

H5: Katılımcıların izleme bileşenine yönelik değerlendirmeleri bağlı oldukları direktörlük gruplarına göre farklılaşmaktadır. 
Tablo 14: Direktörlük Grupları Açısından “İzleme” Bileşenine Yönelik Değerlendirmelerin Farklılaşıp Farklılaşmadığını Ölçen Kruskal-Wallis H Testi Sonuçları

\begin{tabular}{|c|c|c|c|c|c|}
\hline & Birim & $\mathbf{N}$ & $\begin{array}{c}\text { Siralı } \\
\text { Ortalama }\end{array}$ & $\begin{array}{l}\text { Kruskal- } \\
\text { Wallis H }\end{array}$ & $\mathbf{p}$ \\
\hline \multirow[t]{5}{*}{ İzleme } & İş Geliştirme ve Pazarlama & 8 & 25,69 & \multirow[t]{5}{*}{6,552} & \multirow[t]{5}{*}{0,09} \\
\hline & Mali İşler Direktörlüğü & 14 & 31,79 & & \\
\hline & Yönetim Hizmetleri Direktörlüğ̈̈ & 11 & 19,32 & & \\
\hline & Operasyon Hizmetleri Direktörlüğü & 25 & 33,92 & & \\
\hline & Toplam & 58 & & & \\
\hline
\end{tabular}

Birim ile izleme bileşenine yönelik görüşler arasındaki farklılığın olup olmadığını tespit etmeye yönelik yapılan analiz sonucunda, anlamlı bir farklılık olmadığı tespit edilmiştir.H5 hipotezi reddedilmiştir. Biriminin izleme bileşenine yönelik görüşler üzerinde herhangi bir etkisinin olmadığ1 söylenebilir.

\section{SONUC VE ÖNERILER}

Diğer işletmelerde olduğu gibi hastane işletmelerinde de üst yöneticiler tarafindan iç kontrol sisteminin etkin bir şekilde tasarlanması ve uygulanması hizmet sunumunun kalitesini o derece artırır. Yönetim belirlediği hedeflere iç kontrol sistemi sayesinde daha hızlı ulaşabilir. Bundan dolayı kurumun belirlediği hedeflere ulaşabilmesi açısından uluslararası kabul görmüş bir iç kontrol sisteminin faaliyete geçirilmiş olması ve çalışanların çoğunluğunun bu sürece dahil olması oldukça önemlidir. Bu bağlamda çalışmada, birden fazla şubesi bulunan özel bir hastanenin iç kontrol sisteminin, iç kontrol modeli bileşenleri çerçevesinde genel müdürlük bünyesinde çalışanlarca değerlendirilmesi amaçlanmıştır. Bu amaçla bir anket çalışması yapılmıştır. Anket çalışması ile ulaşılan sonuçlar aşağıdaki gibidir:

Araştırmaya katılanların iç kontrol modeline ilişkin ankette yer alan ifadelere yüksek bir oranda $(X=3,81)$ katıldıkları görülmüştür. Alt boyutlar açısından da; en yüksek düzeyli katılımın "izleme" boyutu içerisinde yer alan ifadelere $(\bar{X}=3,98)$, en düşük düzeyli katılımın ise "risk değerlendirme" boyutunda yer alan ifadelere $(X=3,60)$ ilişkin olduğu görülmüştür. $\mathrm{Bu}$ bulgular doğrultusunda katılımcıların kurumun COSO İç Kontrol Modeli bileşenleri ile uyumlu bir iç kontrol sistemine sahip olduğunu ve sisteminin sağlıklı bir biçimde yürütüldüğünü düşündükleri sonucuna varılabilir. Bu sonuç, Kurnaz (2019) tarafından yapılan çalışma ile kıyaslandığında; Kurnaz (2019)'ın çalışmasında; COSO iç kontrol modelinin bileşenleri ile araştırmanın yapıldığı hastanenin iç kontrol sisteminin kısmen uyumlu olduğu sonucuna ulaşıldığg görülmüştür.

Yapılan hipotez testi sonuçlarına göre de; katılımcıların COSO bileşenlerine yönelik değerlendirmeleri açısından, direktörlük grupları arasında anlamlı bir farklılık olmadığı, çalışılan birimin görüşler üzerinde anlamlı bir etkisinin olmadığı görülmüştür.

Ankara ilinde bulunan bir hastane ile sınırlı olan bu çalışma, hastanelerin iç kontrol sistemine uyumunun ortaya konulduğu ender çalışmalardandır. Bu konuda daha fazla çalışma yapılmasına ihtiyaç bulunmaktadır. Yapılan bu çalışmanın, başka hastanelerde de yapılarak alanın genişletilmesi, hastanelerde iç kontrol sistemlerinin ortaya konularak eksikliklerin fark edilerek giderilmesine ve böylece daha kaliteli hizmetin sunulmasına ve işletme yönetiminin amaçlarının gerçekleştirilmesine katkı sağlayacağı açıktır.

\section{KAYNAKÇA}

Aksoy, T. (2005), "Ulusal ve Uluslararası Düzenlemeler Bağlamında İç Kontrol ve İç Kontrol Gerekliliği: Analitik Bir Inceleme”, Mali Çözüm-72 Dergisi, 138-164.

Aytaç, A. (2014), İç Kontrol Sisteminin Etkinliğinin Değerlendirilmesi ve Bir Uygulama. Yüksek Lisans Tezi, Uludağ Üniversitesi Sosyal Bilimler Enstitüsü İşletme Anabilim Dalı Muhasebe Finansman Bilim Dalı, Bursa.

Can, E. N. - Çetin, C. (2016), "Devlet Üniversitelerinde İ̧̧ Kontrol Sisteminin Işsleyişine Yönelik Bir Araştırma”, Girişimcilik ve Kalkınma Dergisi 11 (2), 108-140. 
Ceyhan, İ. F. - Apan, M. (2014), "COSO İç Kontrol Modelinin Yapısal Eşitlik Modeli ile İncelenmesi: Bir Hastane Uygulaması”, Mehmet Akif Ersoy Üniversitesi Sosyal Bilimler Enstitüsü Dergisi 6 (10), 179-198.

Cömert N. (2019), Bütünleşik Yaklaşımla Kobilerde Risk Temelli Iç̧ Kontrol (Bölüm 6: İç Kontrollerle İlgili Teorik Çerçeve İ̧ Kontrol Kavramı), Gazi Kitabevi, Ankara, 119-196.

Dursun G. D. - Akın, S. (2019), “Türkiye'de Özel Hastanelerde İç Kontrol Sisteminin Önemi”, Izmir Democracy University Health Sciences Journal Iduhes 2 (1), 48-60.

Erdoğan, B. - Mengi, B.T. (2018), "Hata ve Hilelerin Önlenmesine Yönelik Kontroller ve Sağllk Sektörü Üzerine Bir Uygulama”, Giresun Üniversitesi İktisadi ve İdari Bilimler Dergisi 4 (8), 85-106.

Fidan, M. - Mumcu, E. Ş. (2019), "Madencilik Sektöründe Faaliyet Gösteren İşletmelerde Iç̧ Kontrol ve Hile Riski: Bir Mermer Isşletmesi Üzerine Inceleme”, Karamanoğlu Mehmet Bey Üniversitesi Sosyal ve Ekonomik Araştırmalar Dergisi, 21 (37), 61-81.

Gökçen, G. - Tipi, O. (2019), "Işsletmelerde Hilelerin Önlenmesine Yönelik İç Kontroller ve BIST Imalat Sektöründe Bir Araştırma", Marmara Üniversitesi İktisadi ve İdari Bilimler Dergisi 41 (1), 145-169.

Gönen, S. (2007), Konaklama Işsletmelerinde Muhasebe Organizasyonu ve İç Kontrol Sisteminin Etkinliğinin Arttırılmasına Yönelik Bir Uygulama. Doktora Tezi, Dokuz Eylül Üniversitesi Sosyal Bilimler Enstitüsü İşletme Anabilim Dalı, İzmir.

Hacıhasanoğlu, T, - Kaya, E (2018), "Üretim İşletmelerindeki İ̧ Kontrol Sisteminin COSO Standartlarına Uyum Derecesinin Belirlenmesi: Kocaeli İli Örneği”, MANAS Sosyal Araştırmalar Dergisi 7 (4), 241-266.

Kara, M. (2018), Kalite Yönetim Sistemleri İle $\dot{I}_{c ̧}$ Kontrol Sistemi Uygulamaları Arasındaki Etkileşimin Değerlendirilmesi ve Bir Araştırma, Doktora Tezi, İnönü Üniversitesi Sosyal Bilimler Enstitüsü İşletme Anabilim Dalı Muhasebe Finansman Bilim Dalı, Malatya.

Kertiş, S. (2005), Hastane İşletmelerinde İ̧̧ Kontrol Sistemi ve Özel Bir X Hastanesinde Uygulanması. Yüksek Lisans Tezi, İstanbul Üniversitesi Sosyal Bilimler Enstitüsü İşletme Anabilim Dalı, İstanbul.

Kurnaz, E. (2020), "Sağllk Sektöründe İ̧̧ Kontrol Sisteminin COSO Iç̧ Kontrol Modeli Bileşenleri Açısından Incelenmesi: Bir Hastane Uygulaması", Mali Çözüm Dergisi, 30 (157), 163-185.

Kurt, G. - Uçma Uysal, T. (2019), Bütünleşik Yaklaşımla Kobilerde Risk Temelli Iç̧ Kontrol (Bölüm 7: Kobi’ler İçin Risk Temelli Kontrol Modeli), Gazi Kitabevi, Ankara, 197-213.

Özgan, H. - Akıncı, E. (2011), Okul Süreç Danışmanlı̆̆ı Ölçeğinin Geliştirilmesi: Geçerlilik ve Güvenilirlik Çalışması, Uluslararası İnsan Bilimleri Dergisi 8 (1), 1131-1149.

Sekaran, U. (1992), Research Methods for Business - A Skill-Building App- Instructor's Resource Guide with Test Questions \& Transparency Masters, John Wiley\&Sons, Incorpo.

Türk, M. - Çil Koçyiğit, S. (2020), Denetimde Seçme Konular 4: İç Denetim İç Kontrol Sektörel Uygulamalar (Bölüm 3: Hastane Işsletmelerinde Risk Değerlendirme Süreci), Gazi Kitabevi, Ankara, 69-88. (Editör: Ü. Aslan ve S. Bozkuş Kahyaoğlu).

Yamane, T. (2001), Temel Örnekleme Yöntemleri (Çev: Alptekin Esin, M. A. Bakır, C. Aydın, E. Gürbüzsel), Literatür Yayınları, İstanbul.

Zorlu, M. (2014), Kar Amacı Gütmeyen Organizasyonlarda Iç̧ Kontrol ve İç Denetim: Bir Devlet Üniversitesinde Uygulama, Hac1 Bektaş Veli Üniversitesi Sosyal Bilimler Enstitüsü İşletme Anabilim Dalı, Nevşehir. 